DOI: $10.31866 / 2410-1915.20 .2019 .172476$

УДК 39(=161.2)(049.32)

\title{
НЕ ШЛЯХ У МИНУВШИНУ, А ДОРОГА... ДО ОРГАНІЧНОГО БУТТЯ НАРОДУ В НОВИХ УМОВАХ
}

\section{Горбань Юрій Іванович}

Кандидат культурології, ORCID:0000-0001-5837-4409, y.i.gorban@gmail.com, Київський національний університет культури і мистецтв, вул. Є. Коновальия, 36, Київ, Україна, 01133

Рецензія на монографію: Ткач М. М. Українська звичаєва культура. Київ: Лipa-K, 2018. 592 c.

Останнім часом об’єктом наукових досліджень стає культура, духовне життя та побут народу. Народна культура цікава своєю самобутністю та неповторністю. Говорячи про українські звичаї, культуру, традиції, важливо розуміти, що це не вкорінені звички, устрій практичної та суспільної діяльності, а національна спадщина, народна культура, що передається з покоління в покоління. Це характерна риса, що виокремлює український народ серед інших, риса, що дозволяє пам’ятати, відчувати те, що ми $є$ частиною великого народу. Пам’ятаючи та зберігаючи традиції, людина отримує вікову опору свого народу, належну підтримку.

Актуальність і своєчасність монографії Ткача М. М. «Українська звичаєва культура» зумовлена тим, що традиційна обрядовість і система свят відіграє в усі часи важливу роль у побуті будь-якого етносу. Обрядовість, отримавши семіотичне осмислення та ритуалізовані форми відповідно до системи світосприйняття, міфології та картини світу, створювала ключові моменти людського буття і брала участь у забезпеченні репродукції даної етнічної групи і її традиційної народної культури. Ця обставина робить аналіз традиційної звичаєвої культури невіддільною частиною комплексного вивчення етнічних спільностей, оскільки без такого аналізу неможливо створити уявлення про побутову культуру етносу в цілому. Українська звичаєва культура - це не лише один з основних компонентів духовного життя соціуму, а й складний комплекс, що поєднує духовну й матеріальну сторони традиційного побуту.

Існує необхідність актуалізації українських народних обрядів та свят, оскільки фольклор сьогодні не лише не втратив свого значення, а й отримав широке розповсюдження в найрізноманітніших сферах суспільного життя. Питання збереження і розвитку української звичаєвої культури особливо актуальні в наш час, а проблеми, пов'язані з пошуком нових підходів передачі традиційної народної творчості й нині викликають великий інтерес у багатьох дослідників.

(C) Горбань Ю. І., 2019 
На сучасному етапі найбільшу зацікавленість представляють дослідження явищ традиційної народної культури, що знаходяться на перетині матеріального й духовного. Саме в роботі Миколи Михайловича Ткача спостерігається тенденція вивчення об'єктивних форм культури в системі традиційного обряду.

В основі монографії лежить спроба зберегти духовний родовід та уявлення про традиційний святковий обряд як семіотично осмислену і ритуалізовану форму української звичаєвої культури. Ткач М. М. доводить, що українська звичаєва культура - це багатовіковий концентрований досвід народу, матеріалізований в предметах мистецтва та побуту: це традиції, обряди, звичаї, вірування.

Специфіка етнологічних досліджень на сучасному етапі виявляється в їх розширенні, в здійсненні багатоаспектного вивчення проблеми шляхом поєднання етнографії, фольклористики, лінгвістики, психології, культурології та ін.

Очевидно, що ця монографія - дуже своєчасна наукова робота, яка спирається на глибокі теоретичні аспекти, конкретно-соціологічний аналіз та узагальнення вітчизняних й закордонних досліджень з етнології.

Українцям знадобилося не одне століття, щоб православні свята, які були сформовані на чужій українському культурному підгрунті землі, увібравши в себе різноманітні елементи як давньоруських, так і давньослов’янських дохристиянських святкувань, переосмислених православною церквою, отримали нове забарвлення та стали домінантними в українській звичаєвій культурі.

Автор правильно підійшов до структуризації й розміщення матеріалу (монографія складається з переднього слова від автора, вступу, чотирьох розділів та списку використаних джерел). Широка джерельна база, яка свідчить про те, що автор глибоко ознайомлений 3 теоретичними та методологічними підходами до питань української звичаєвої культури, проблемами, які сьогодні існують у народознавстві (українознавстві).

У вступі особлива увага приділена терміну «народознавство» (українознавство) та окресленню його напрямів діяльності. Також порушується питання усвідомлення культури на основі висновку, де зазначається, що поняття культура із самого початку було невіддільним від духовної й матеріальної діяльності людини - ії взаємовідносин 3 Богом, із культом певного божества. На основі матеріалів наукових праць Н. М. Гальковского, К. Леві-Строс, Г. Сковороди, В.Шаяна та ін. автор розкриває сутність віри та системи вірувань і зазначає, що живучість віри в тому, що вона охоплює все життя людини. На його думку, віра - це така психологічна особливість людини, яка служить їй опертям у всіх діях і вчинках, у вирішенні будь-яких життєвих проблем.

Перший розділ «Звичаєва традиція українців» присвячений звичаям i розвитку буття, а також різновидам звичаїв. Викликає зацікавлення думка автора про те, що людина, здобувши додаткову енергію у вигляді потаємних знань про природу буття та шляхом візуальних і практичних спостережень за довкіллям, свідомо вийшла із лона дикої природи 
й створила свій окремий людський світ, відповідальність за який вона взяла на себе. Також Ткач М. М. акцентував увагу на таких поняттях як гріх і звичай, дав їм визначення і окреслив їх вплив на буття людини. Щодо різновидів звичаїв, то науковець стверджує, що все розмаїття існуючих звичаєвих норм і правил поведінки людини можна розмежувати на дві течії: перша внормовує поведінку людини й роду, наслідки порушень якої виявляються безпосередньо на самій особі (родовій одиниці чи племені), друга - поведінку людини, наслідки порушення якої виявляються в певних змінах середовища довкілля (природного й суспільного).

У другому розділі «Обрядова традиція українців» автор намагається сформулювати цілісне уявлення про обряд. I на основі вивчення наукових праць дає власне визначення обряду, визначає та розкриває структуру традиційного українського обряду (зачин, основне дійство, завершальне дійство). Корисним $є$ матеріал про основні чинники обрядового дійства, засобами яких розкривається суть першопричини обрядового дійства, а також здійснюється символічний вплив на середовище непроявленого буття. Також Ткач М. М. наводить класифікацію різновидів традиційних обрядів українців (родинні, календарні, громадські, побутові, господарські, землеробські).

Належну увагу в третьому розділі «Основні календарні свята українців» присвячено висвітленню поняття свята та його класифікації. Відповідно до властивих їм ознак, всі свята можна розподілити за: приналежністю; характером, обставинами побутування. За приналежністю свята розподіляються на: особисті, колективні, родинні, національні, громадські, релігійні, державні, народні. Основну частину розділу складає перелік календарних свят (Різдво, Василя, Водохреща, Свято Стрітення, Свято Івана Купала, Свято пророка Іллі, Свято Покрови, та ін.), їх детальний опис, дата святкування, історія походження й всебічне розкриття деталей та особливостей.

Останній, четвертий розділ «Родинні свята та обряди українців» детально описує та характеризує Обряд українського весілля, Родини, Хрестини, Порожини та пострижини, Похоронні обряди. Для кращого розуміння сутності та особливостей проведення обрядів, автор монографії використовує тексти балад, пісень, пританцівок, голосіння, примовляння з різних регіонів України, що також дає можливість зробити самостійний аналіз та відшукати спільні й відмінні риси.

Особлива увага приділяється таким термінам як культура, традиція, духовність, віра, обряд та їх сутності, функціям в наукових роботах Г. О. Булашева, В. М. Гнатюка, Н. О. Данилевської, С. Килимника, І. Франка, А. Швейцера та ін.

Цінність монографії підвищується тим, що зібрані в ній матеріали $\epsilon$ працею понад двадцяти п’яти річної наукової діяльності Ткача Миколи Михайловича. Значна частина вміщеного в ній матеріалу була оприлюднена у періодичних виданнях України, починаючи з 1990-х років. Зокрема, друкувався цикл статей у скороченому варіанті про сутність звичаю та обряду, про символ та різновиди символіки, світогляд пращу- 
рів, календарні звичаї та обряди українців, у яких були спроби розкрити біологічну, генетичну й астральну природу народної звичаєвості та обрядовості. Завдяки цій науковій роботі вперше у вітчизняній етнології здійснено комплексний аналіз звичаєвої традиції українців, визначено роль обрядів, звичаїв, вірувань в формуванні та розвитку культури.

За часів викладання в Київському національному університеті культури і мистецтв, кандидат історичних наук, професор Микола Михайлович Ткач використовував та апробував як лекційні матеріали всі свої напрацювання у програмах з навчальних дисциплін, що пов’язані 3 традиційною культурою, міфологією та фольклором, удосконалював і доповнював їх новими статтями й положеннями.

Аналіз особливостей українських народних обрядів і свят, традицій, звичаїв, показав, що кожен вид та жанр традиційної культури, як і система загалом, мають стійке стереотипне ядро, і в діалектичній єдності зі стереотипністю варто розглянути й варіативність. Розгляд основних функцій українських народних свят, обрядів виявив їх взаємозв'язок і спрямованість на головну ціль - збереження та розвиток етносу, без якого неможливе існування індивіда.

Дослідження має багатоаспектне значення, переважно може бути використане для розробки спеціальних курсів з культурології, етнографії, історії української культури.

Монографія має високий науковий рівень, вирізняється новизною в розкриті складних тем, безперечно, заслуговує високої оцінки і займе достойне місце серед досліджень у галузі культурології. Щоб зрозуміти масштаб і всю значущість дослідження, необхідно усвідомити, що це остання робота кандидата історичних наук, професора, поета, лауреата літературних премій «Благовіст», імені Михайла Коцюбинського, Міжнародної премії імені Григорія Сковороди «Сад божественних пісень», імені Пантелемона Куліша М. М. Ткача. Усі роки свого життя Микола Михайлович не припиняв роботу над вивченням та відродженням історичної пам'яті та не лише готував нові тексти, а й продовжував дослідницьку діяльність (саме авторству М. М. Ткача, знавця старослов'янської писемності, належать перший в Україні «Словник-довідник «Слова о полку Ігоревім» та наукова реконструкція українською абеткою тексту цієї літературної пам'ятки).

Людина світлої щедрої душі, поет Божою милістю, залишив низку поетичних збірок, емоційних і філософічних, а найголовніше - органічних, зрозумілих. Назва однієї з них - «Не осквернись, душе моя, у слові!» звучить як життєве кредо поета.

Монографія «Українська звичаєва культура» написана доступною мовою, містить цінний теоретичний і практичний матеріал та буде корисна й цікава для студентів, аспірантів, науково-педагогічних працівників закладів вищої освіти, а також усіх тих, кому не байдужі питання українських національних традицій та культури. 